\title{
Effects of carbadox or formic acid and diet type on ileal digestion of amino acids by pigs
}

\author{
K. Partanen, J. Valaja, Hilkka Siljander-Rasi, T. Jalava and S. Panula
}

\author{
Agricultural Research Centre of Finland, \\ Animal Production Research \\ 31600 Jokioinen, Finland
}

\begin{abstract}
Endogenous flows and true ileal digestibilities of amino acids were determined with the homoarginine method in growing pigs fed barley-soyabean meal or by-product-soyabean meal diets plus $50 \mathrm{mg} / \mathrm{kg}$ carbadox, or $8 \mathrm{~g} / \mathrm{kg}$ formic acid $(85 \% \mathrm{v} / \mathrm{w})$ or without either of these additives. Seven barrows (one reserve) equipped with T-cannulae according to the steered-ileo-caecal-valve method were fed these diets in a $6 \times 4$ cyclic change-over design from 39 to $83 \mathrm{~kg}$ live weight. Both carbadox and formic acid improved the apparent ileal digestibilities of several essential amino acids in the byproduct-based diet but not in the barley-based diet. The improvements were due to reduced endogenous amino acid losses. Neither carbadox nor formic acid affected the true ileal digestibility of lysine.
\end{abstract}

KEY WORDS: amino acids, ileal digestion, pigs

\section{INTRODUCTION}

Antimicrobial feed additives are commonly used in grower diets in order to promote the performance of pigs and prevent diseases. However, concern over increased bacterial resistance to drugs caused by the routine use of antimicrobials has led to a search for alternatives, such as organic acids. Organic acids have been shown to enhance the performance of growing pigs (Baustad, 1993; Øverland and Lys $\varnothing, 1997)$, but information about their modes of action is scarce. It has been suggested that dietary acidification limits microbial growth, increases enzyme activities and improves protein digestion (Kirchgessner and Roth, 1988). Mosenthin et al. (1992) and Kemme et al. (1995) have reported improved apparent ileal digestibilities (AID) of amino acids, by 2 to $7 \%$-units, in growing pigs fed acidified 
diets. The observed variation in the digestibility responses may be due to differences in the dose and type of acid used, as well as in the diet composition. Whether the improved AID are due to decreased endogenous nitrogen losses (ENL) or increased true ileal digestibilitics (TID) is not known. Thus, we studied the effects of carbadox and formic acid on the AID and TID of amino acids in growing pigs fed simple barley-based or complex by-product-based diets.

\section{MATERIAL AND METHODS}

A barley-based ( $765 \mathrm{~g} / \mathrm{kg}$ barley, $211 \mathrm{~g} / \mathrm{kg}$ soyabean meal) and a by-productbased diet $(566 \mathrm{~g} / \mathrm{kg}$ barley, $199 \mathrm{~g} / \mathrm{kg}$ soyabean meal, $180 \mathrm{~g} / \mathrm{kg}$ wheat bran-middlings, $20 \mathrm{~g} / \mathrm{kg}$ wheat syrup, $12 \mathrm{~g} / \mathrm{kg}$ rape seed oil) were formulated to be similar in energy $(9.1 \mathrm{MJ} \mathrm{NE} / \mathrm{kg})$ and lysine content $(7.8 \mathrm{~g} / \mathrm{kg})$ and to meet the vitamin and mineral requirements of growing pigs. Either $50 \mathrm{mg} / \mathrm{kg}$ carbadox, or $8 \mathrm{~g} / \mathrm{kg}$ formic acid $(85 \%, \mathrm{v} / \mathrm{w})$ or no additives were included in these diets. Seven barrows (one reserve) equipped with $\mathrm{T}$-cannulae according to the stecred-ilco-caccalvalve method (Mroz et al., 1996) were fed these diets in a $6 \times 4$ cyclic change-over design from 39 to $83 \mathrm{~kg}$ liveweight. The feeds were given twice daily by liveweight $\left(90 \mathrm{~g} \mathrm{feed} / \mathrm{kg} \mathrm{W}^{0.75} / \mathrm{d}\right)$ in the form of wet mash (water to feed $=1.5: 1$ ). Chromium-mordanted straw $(71 \mathrm{~g} \mathrm{Cr} / \mathrm{kg})$ was used as marker $(1.6 \mathrm{~g} / \mathrm{kg}$ feed).

Ileal digesta were collected on d 10 and $\mathrm{d} 14$ for $12 \mathrm{~h}$ to determine the AID and TID, respectively. To determine the TID and endogenous flow of lysine, the pigs were fed diets in which $50 \%$ of soyabean meal was replaced with guanidinated soyabean meal prepared in a $0.6 \mathrm{M} \mathrm{O}$-methylisourea solution at $\mathrm{pH} 10.5$ for $6 \mathrm{~d}$ (Imbeah et al., 1996). Prior to the homoarginine feeding, the pigs were fed three protein-free meals. Endogenous flows of other amino acids were calculated in relation to lysine by using the endogenous amino acid profile determined by de Lange et al. (1990).

Amino acids and homoarginine were analysed by Biochrom 20 Amino Acid Analyser after hydrolysis in $6 . \mathrm{M} \mathrm{HCl}$ at $110^{\circ} \mathrm{C}$ for $23 \mathrm{~h}$. For methionine and cystine analysis, the performic acid oxidation (at $0^{\circ} \mathrm{C}$ for $16 \mathrm{~h}$ ) was performed prior to the hydrolysis. The data were subjected to a least-squares analysis of variance with the effects of animal, period, diet and additive and diet $x$ additive interaction in the model. The differences between the additives were compared by the orthogonal contrasts: no additives vs carbadox/formic acid and carbadox vs formic acid.

\section{RESULTS AND DISCUSSION}

Carbadox and formic acid improved the AID of several amino acids in the byproduct-based diet, but not in the barley-based diet (Table 1). Similar improve- 


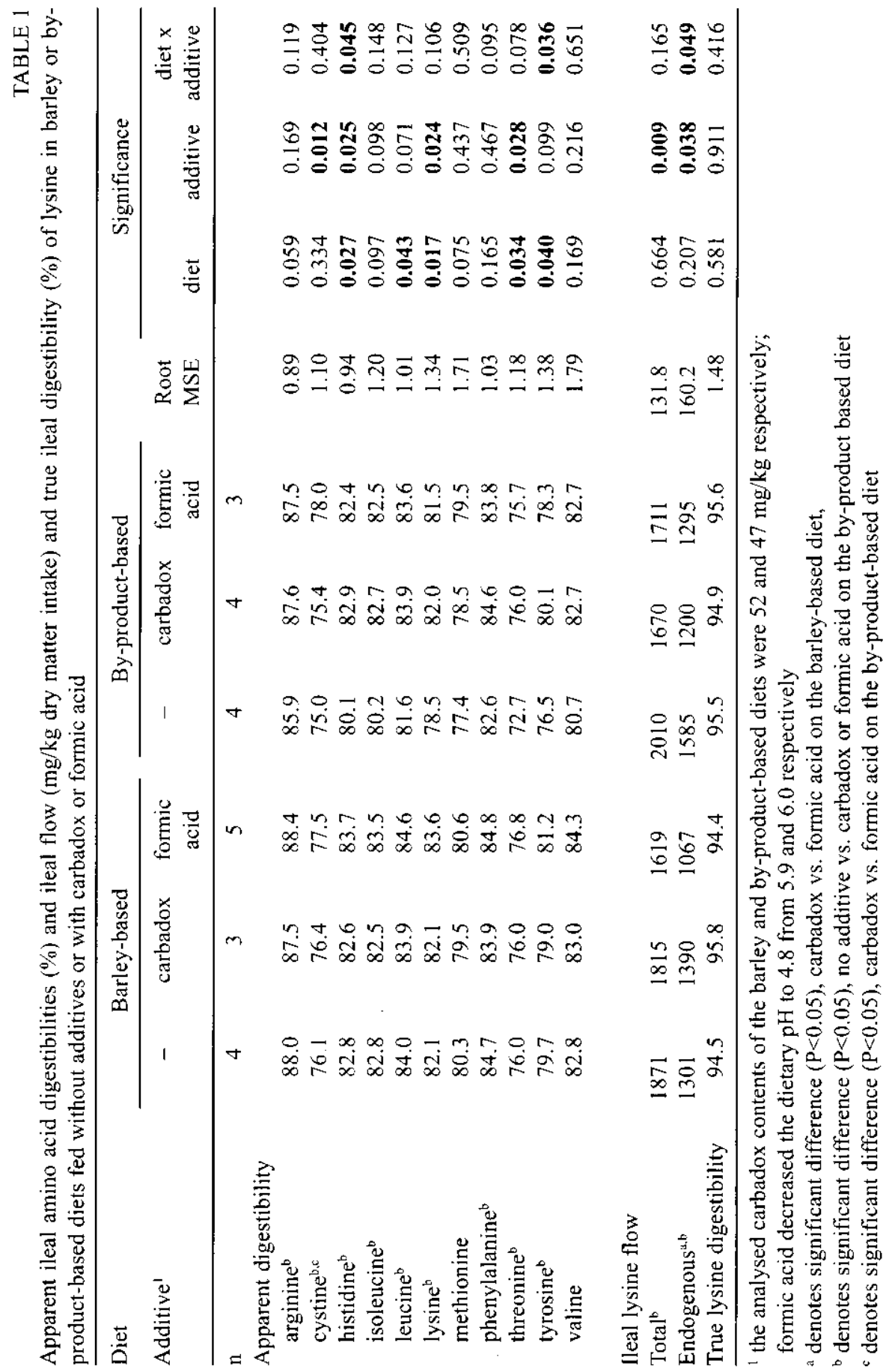


ments in the AID of amino acids have been previously observed in growing pigs following dietary acidification (Mosenthin et al., 1992; Kemme et al., 1995). In those studies the digestion response was greater when a by-product-based diet (Mosenthin et al., 1992) was used rather than a maize-soyabean meal diet (Kemme et al., 1995). Carbadox improved (Yen et al., 1976) or had no effect on the apparent total tract digestibility of protein (Danielsen and Oksbjerg, 1990), whereas information about its effects on the AID of amino acids is limited.

The observed improvements in the AID of amino acids in the by-product-based diet were due to reduction in the ENL. The additives did not affect the TID of lysine or other amino acids. The ENL mainly consists of undigested pancreatic juice, bile, mucus and sloughed cells, but the contribution of bacterial protein can increase considerably with dietary fibre (Schulze et al., 1994). The higher neutral detergent fibre content in the by-product based diet ( $219 \mathrm{vs} 188 \mathrm{~g} / \mathrm{kg}$ dry matter (DM)) increased the endogenous lysine flow by $284 \mathrm{mg} / \mathrm{kg}$ DM intake. Because both antimicrobial feed additives and organic acids inhibit microbial growth (Kirchgessner and Roth, 1988), the decrease in the ENL in the by-product-based diet may reflect a decrease in bacteria-produced protein in the ileal digesta (Schulze et al., 1994).

In conclusion, carbadox and formic acid appear to improve the AID of amino acids by reducing ENL rather than by improving the TID of amino acids, although these effects seem to depend on diet composition. A reduction in ENL will not only contribute to a reduction in nitrogen excretion, but will also improve the efficiency of dietary amino acid utilisation for growth.

\section{ACKNOWLEGEMENTS}

The financial support from Kemira Chemicals Ltd, Helsinki, Finland, and Rehuraisio Ltd., Raisio, Finland is gratefully acknowledged.

\section{REFERENCES}

Baustad B., 1993. Effects of formic acid on performance in growing pigs. Norweg. J. Agric. Sci. 7 , $61-69$

Danielsen V., Oksbjerg N., 1990. The effect of carbadox and tylosin as feed additives in diets for young weaned pigs. World Rev. Anim. Prod. 25, 45-47

de Lange C.F.M., Souffrant W.B., Sauer W.C., 1990. Real ileal protein and amino acid digestibilities in feedstuffs for growing pigs as determined with the $15 \mathrm{~N}$-isotope dilution technique. J. Anim. Sci. $68,409-418$

Imbeah M., Angkanaporn K., Ravindran V., Bryden W.L., 1996. Investigation on the guanidination of lysine in proteins. J. Sci. Food Agric. 72, 213-218 
Kemme P., Jongbloed A.W., Mroz. Z., Mäkinen M., 1995. Apparent ileal amino acid digestibility in pigs as affected by phytate. microbial phytase, and lactic acid. J. Anim. Sci. 73, Suppl. 1, 173

Kirchgessner M., Roth F.X., 1988. Ergotrope Effekte durch organische Säuren in der Ferkelaufzucht und Schweinemast. Übers. Tierernähr. 16, 93-108

Mosenthin R., Sauer W.C., Ahrens F., de Lange C.F.M., Bornholdt U., 1992. Effect of dietary supplement of propionic acid, siliceous earth or a combination of these on the energy, protein and amino acid digestibilities and concentrations on microbial metabolites in the digestive tract of growing pigs. Anim. Feed Sci. Technol. 37, 245-255

Mroz Z., Bakker G.C.M., Jongbloed A.W., Dekker R.A., Jongbloed R., van Beers A., 1996. Apparent digestibility of nutrients in diets with different energy density, as estimated by direct and marker methods for pigs with or without ileo-cecal cannulas. J. Anim. Sci. 74, 403-412

$\emptyset$ verland M., Lys $\emptyset$ A., 1997. Addition of formic acid and/or formates in diets for growing-finishing pigs. Proceedings of $48^{\text {th }}$ Annual Meeting of the EAAP Vienna, Austria, p. 6

Schulze H., van Leeuwen P., Verstegen M.W.A., Huisman J., Souffrant W.B., Ahrens F., 1994. Effect of level of dietary fiber on ileal apparent digestibility and ileal nitrogen losses in pigs. J. Anim. Sci. 72, 2362-2368

Yen J.T., Jensen A.H., Bajjalieh N.H., Ladwig V.D., 1976. Effects of methyl-3-(2-quinoxalinmethylene) carbazate- $\mathrm{N}^{1}, \mathrm{~N}^{4}$-dioxide on nitrogen and energy digestibility in and performance of young pigs. J. Anim. Sci. 42, 375-380 